\title{
At the bathhouse: Municipal reform and the bathing commons in late imperial St. Petersburg
}

\section{An authoritarian state and form of commoning in commercial bathhouses in late imperial St. Petersburg}

Olga Petri

op257@cam.ac.uk

Department of Geography, University of Cambridge, Emmanuel College, 55 St. Andrew's street, CB2 3AP, UK

Abstract

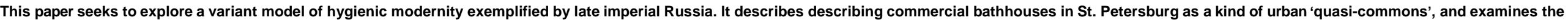

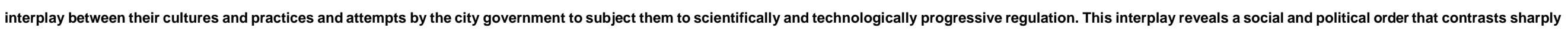

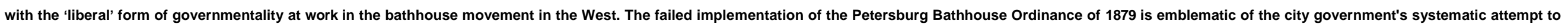

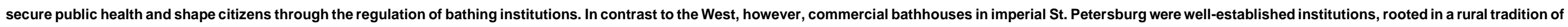

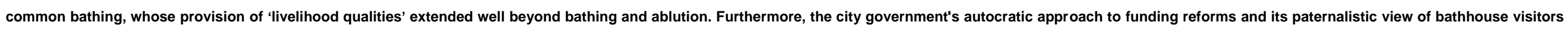

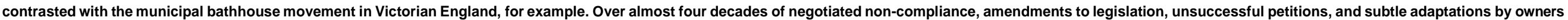

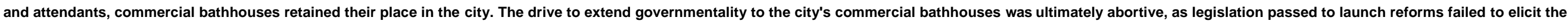

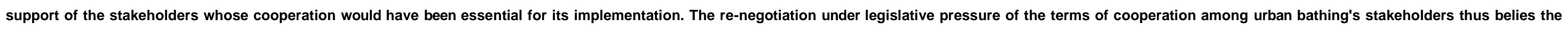
supposedly general trend in bathing from the communal to the private or municipal during the period.

Keywords: Russia; Bathhouses; Commons; Governmentality; Hygienic modernity

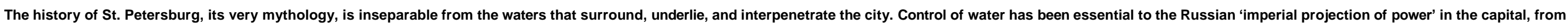

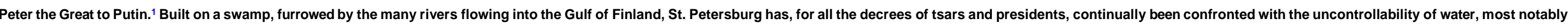

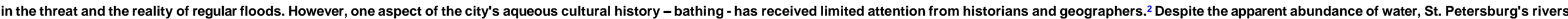

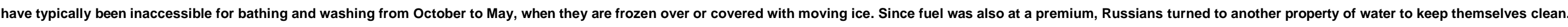

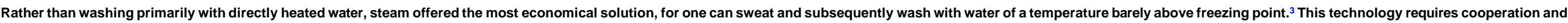

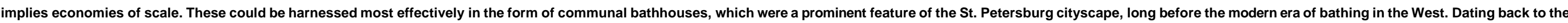

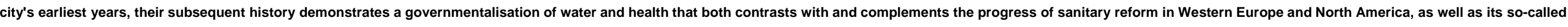

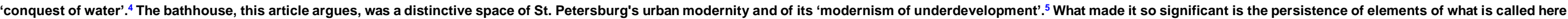

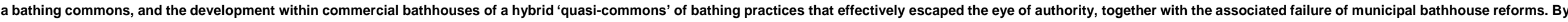

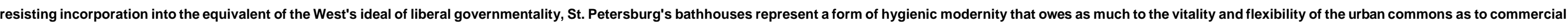
capitalism or governmental authority alone.

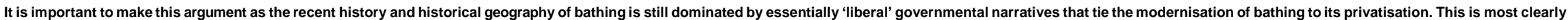

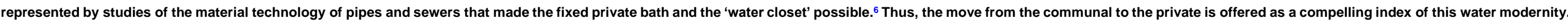

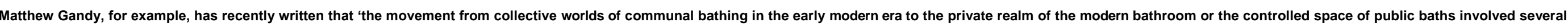

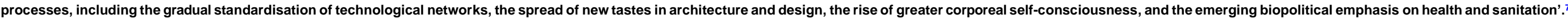

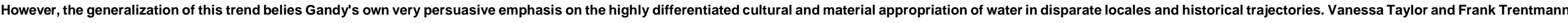

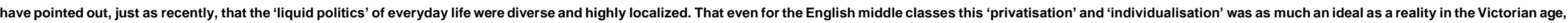




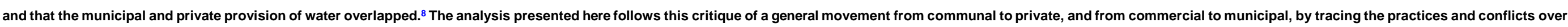

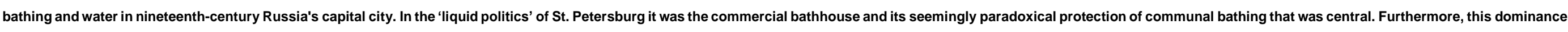

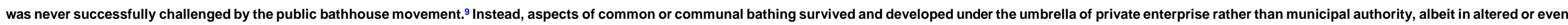

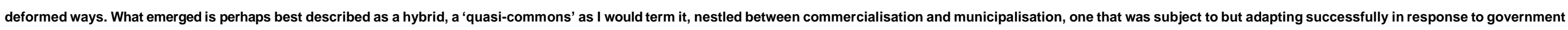
regulation.

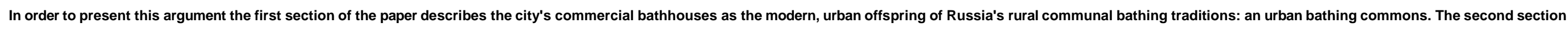

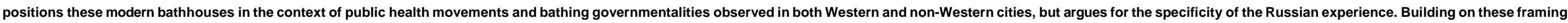

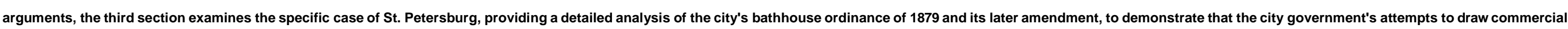

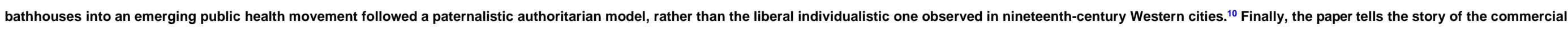

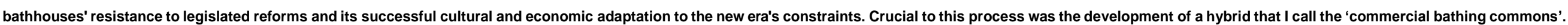

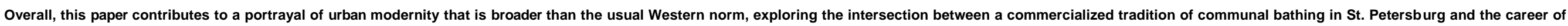

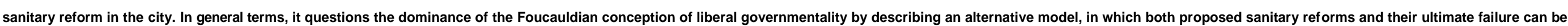

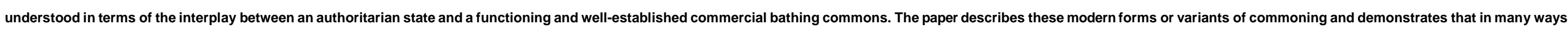

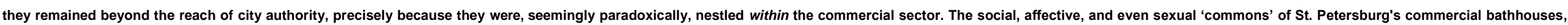

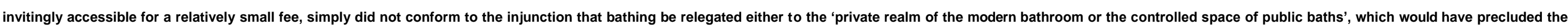

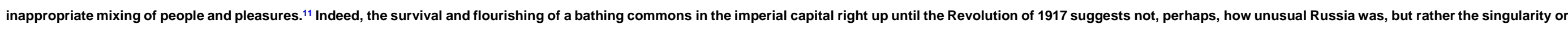
oddity of the Western experience.

\section{The imperial bathhouse and the commercial bathing commons}

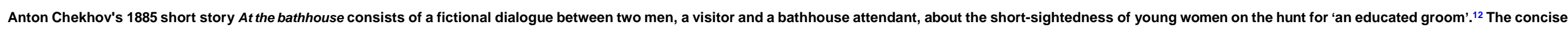

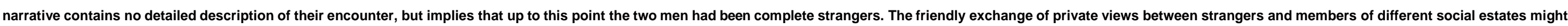

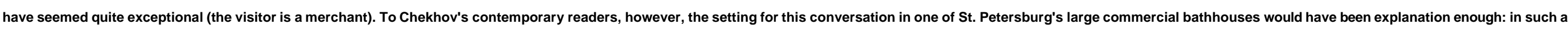

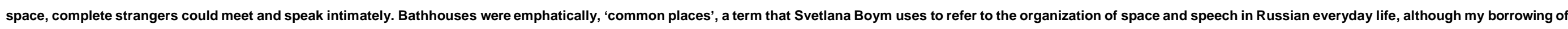
the phrase sees more vitality and persistence in the idea of the 'common' than Boym's history of aestheticized derogation and nostalgia. ${ }^{13}$

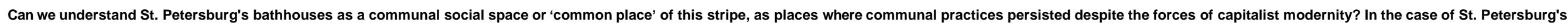

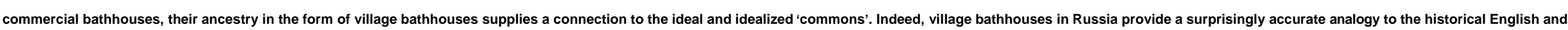

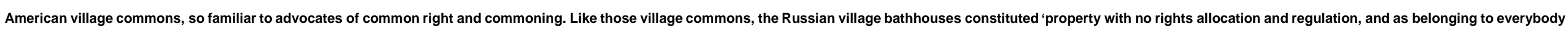
and hence to nobody'. ${ }^{14}$

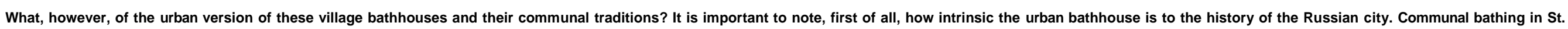

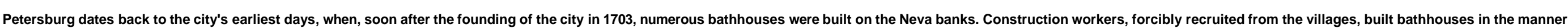

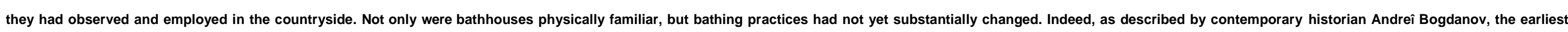

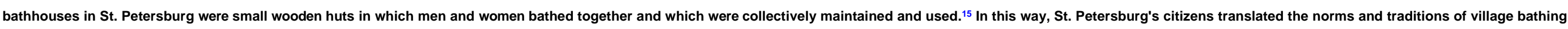
cultures to the city, and in so doing implicitly asserted their right to such amenities.

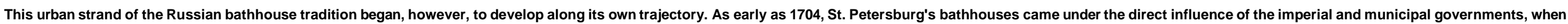

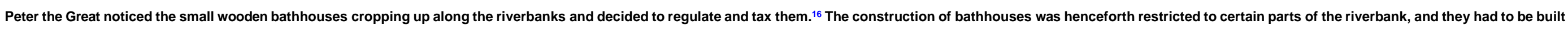

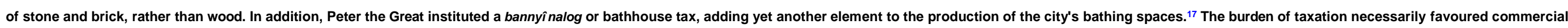

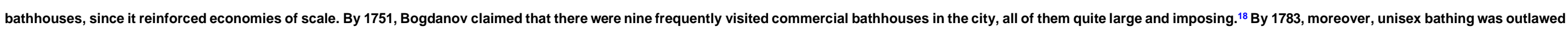




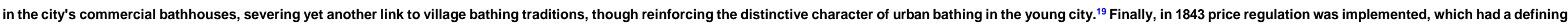

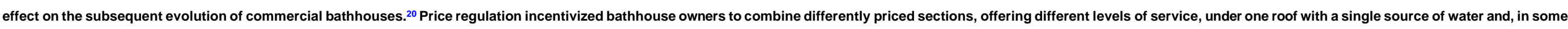

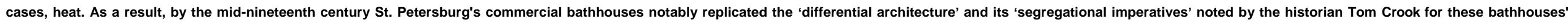
equivalents in Victorian Britain. ${ }^{21}$

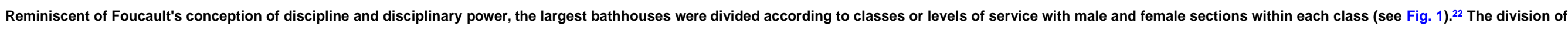

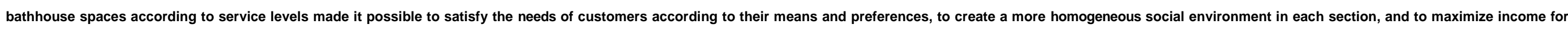

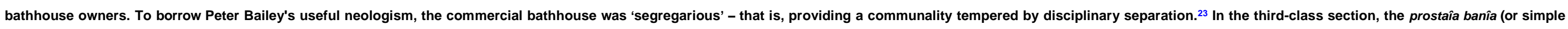

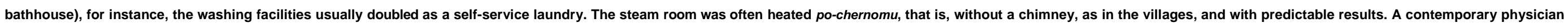

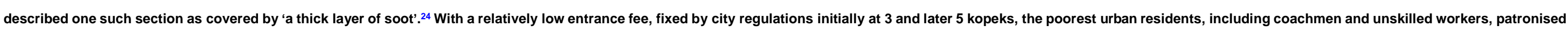

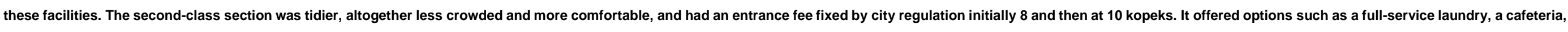

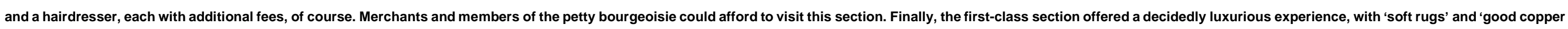

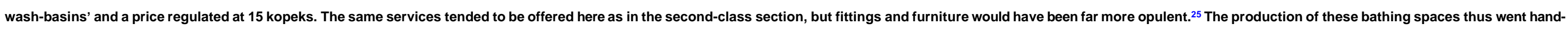

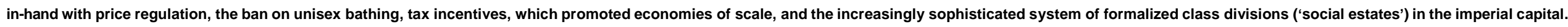

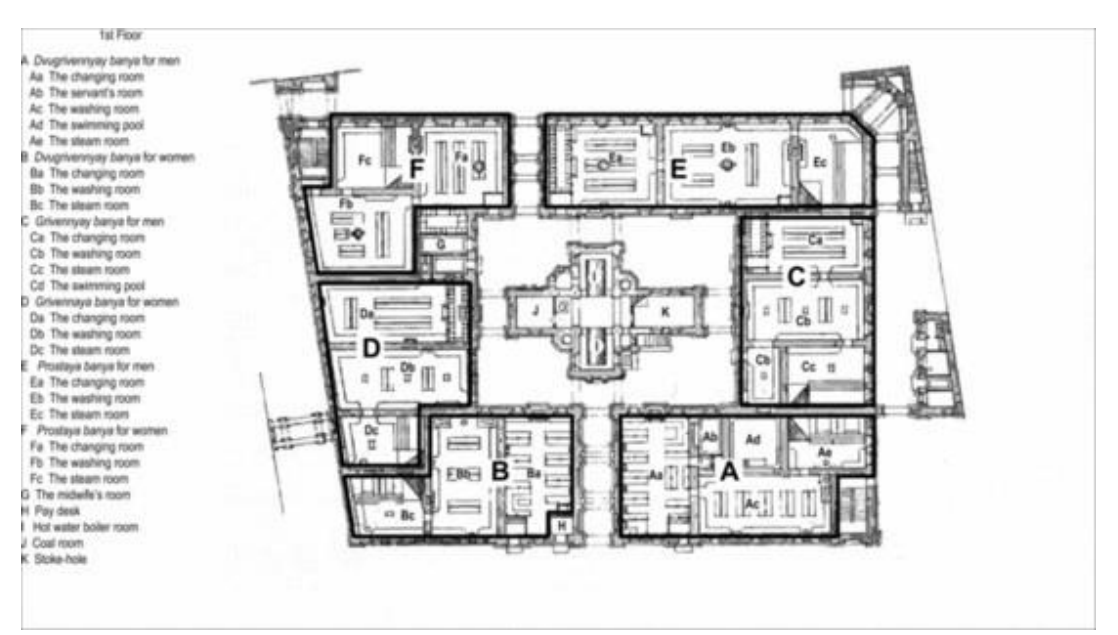

Fig. 1 The layout of Voronin Bathhouse. First floor. Source: P.Ju. Sjuzor, Torgovije (narodnie) bani.

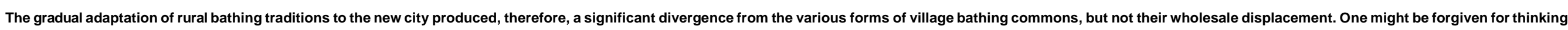

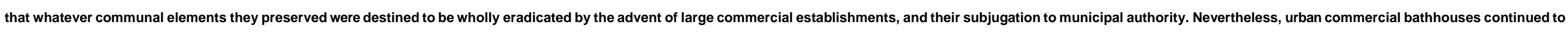

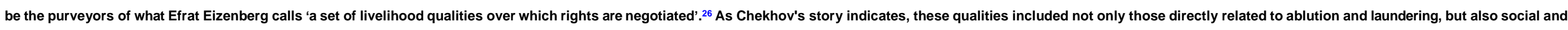

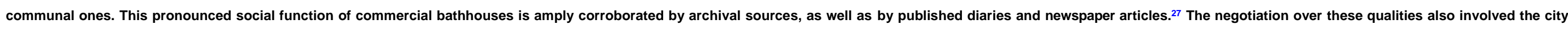

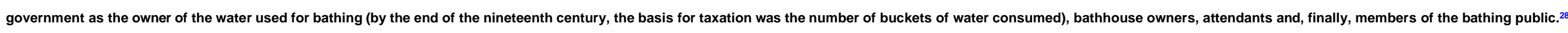

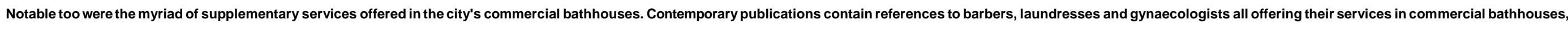
as well as restaurant-style kitchens and laundries being operated by bathhouse owners or franchisees. ${ }^{29}$

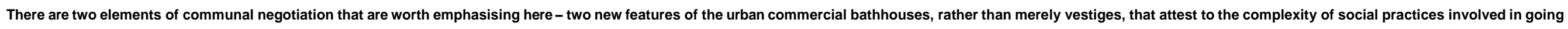

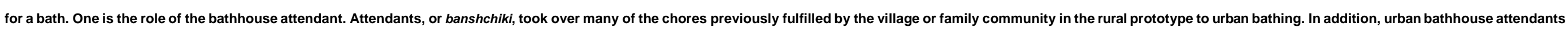

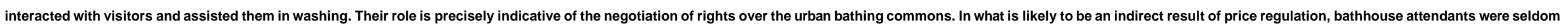




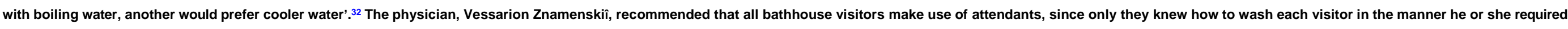
(see Fig. 2, which, although a staged and stylized photograph, illustrates the role of attendants in bathing). ${ }^{33}$

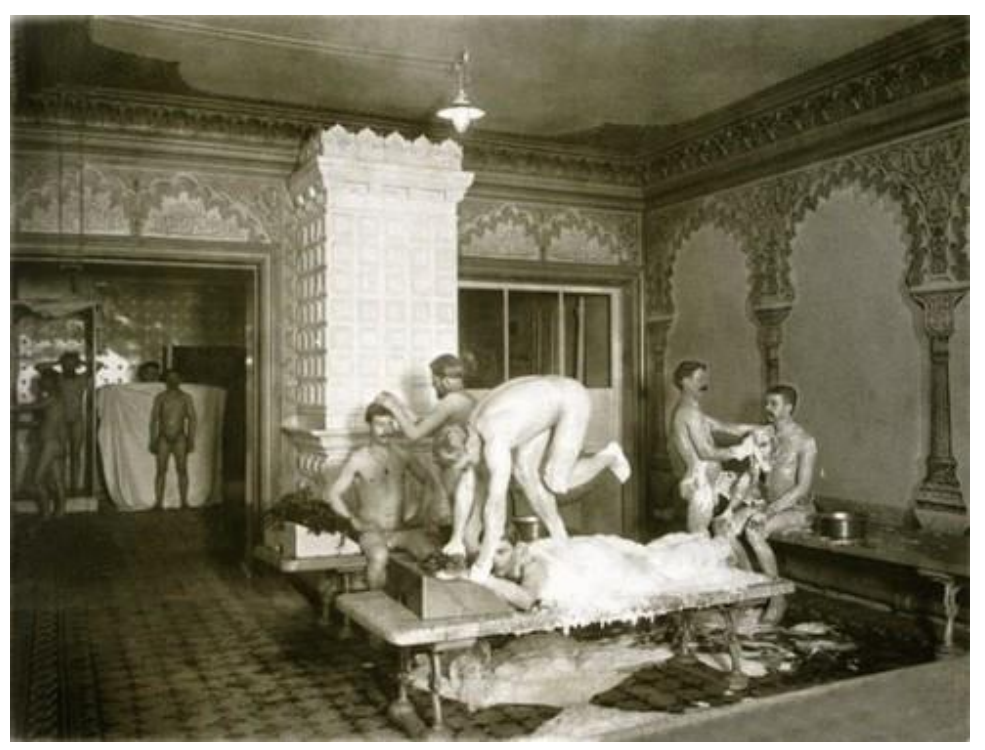

Fig. 2 The washing room with bathhouse attendants doing the washing. Source: Tsentral'nye bani (byvsh.) Yegorova, Sankt-Peterburg, 1897.

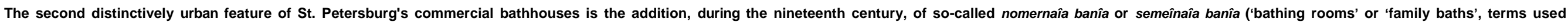

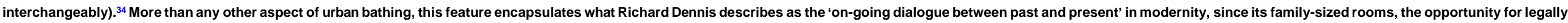

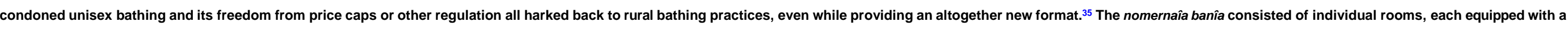

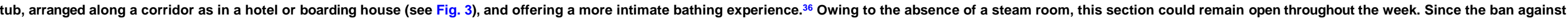

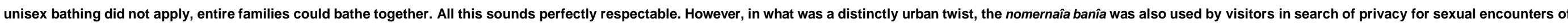

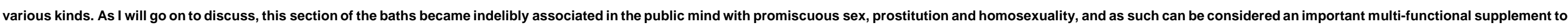
the large open areas of the bathhouse sections described above. ${ }^{37}$ 


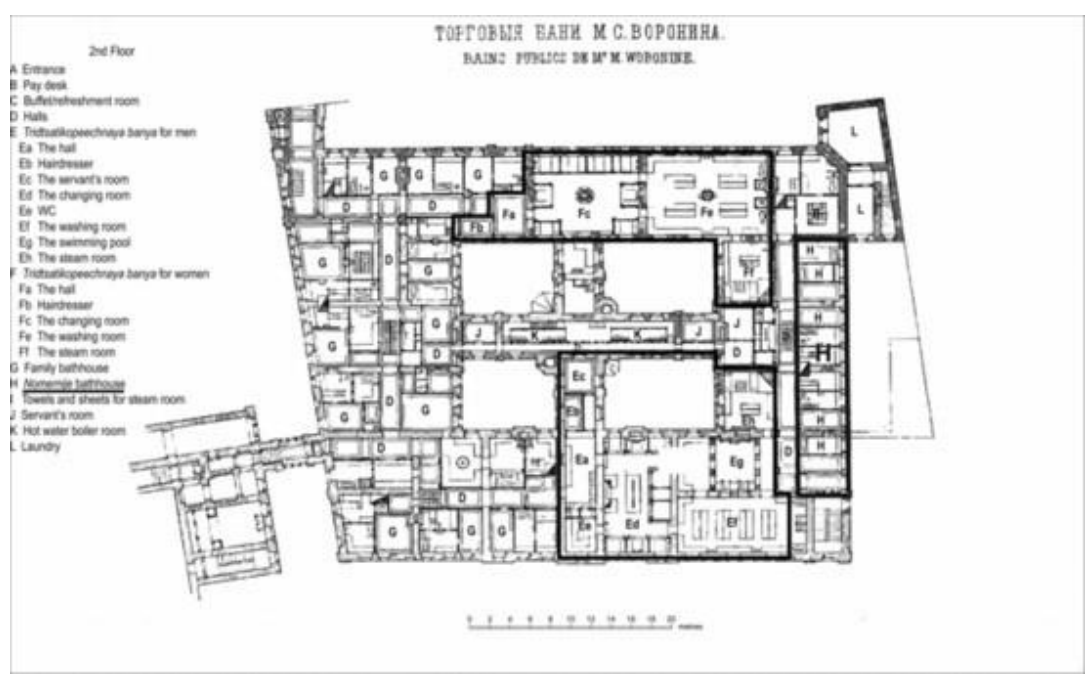

Fig. 3 Voronin bathhouse. Nomernaya banîa (section $\mathrm{H}$ ). Source: as for Fig. 1.

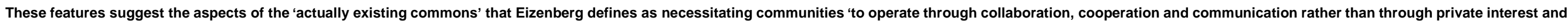

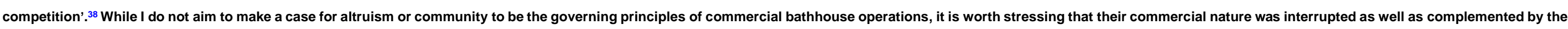

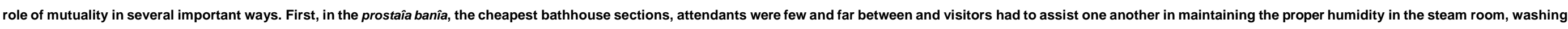

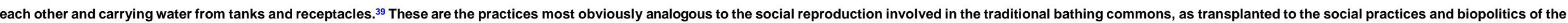

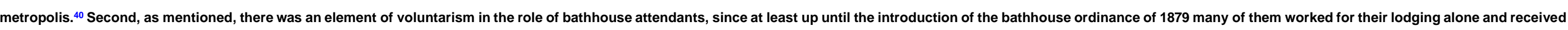

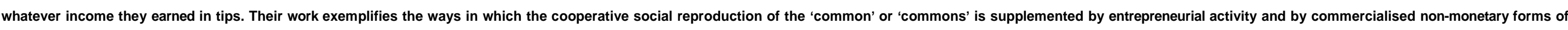

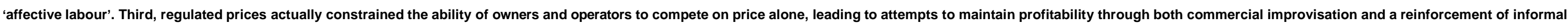
cooperative and self-regulating activities, both licit and illicit. ${ }^{41}$ We might see this as the full or fuller commercial co-option of commoning and affective labour.

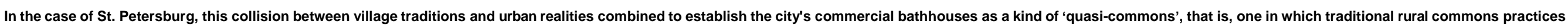
persisted but were also supplemented and coopted by commercial imperatives, all of which evolved in response and resistance to the changes in municipal legislation to which I now turn.

\section{Government regulation of public bathing in St. Petersburg}

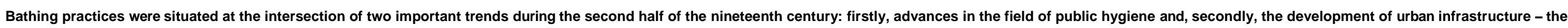

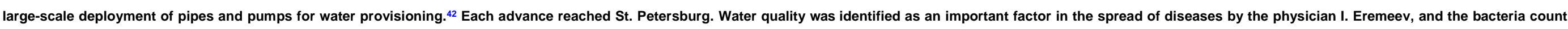

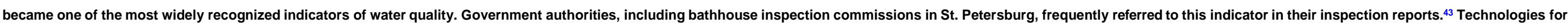

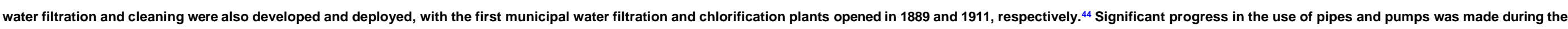

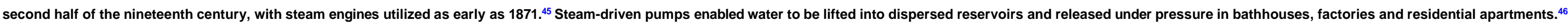

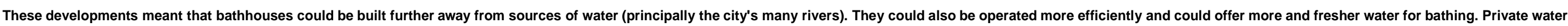
pipes and networks built by corporate utilities coexisted from 1862 until the creation of a municipal network in 1892 via the city government's acquisition of St. Petersburg's two largest water companies. ${ }^{47}$

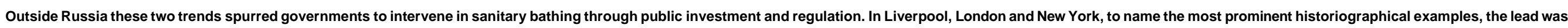

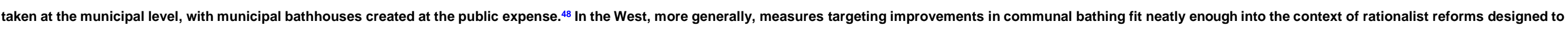

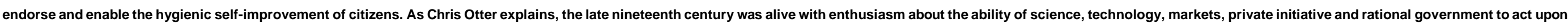

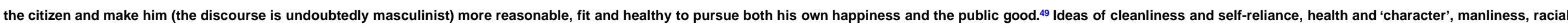




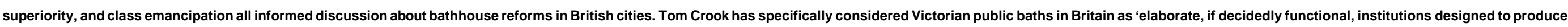

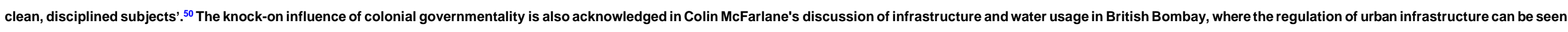

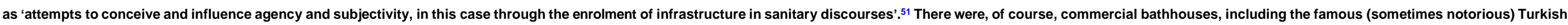

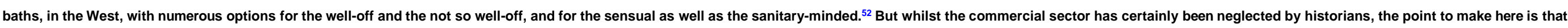

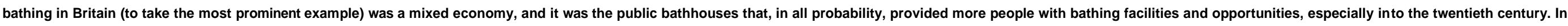
Russia, by contrast, it is the predominance of the commercial bathhouses, and the complete absence of a municipal sector, that is so noticeable.

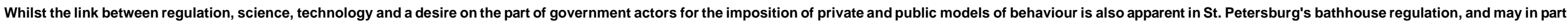

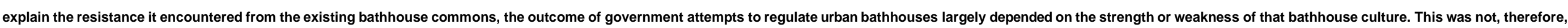

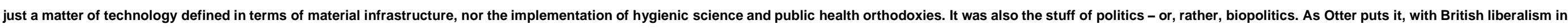

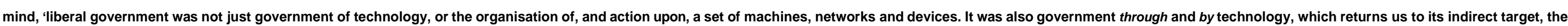

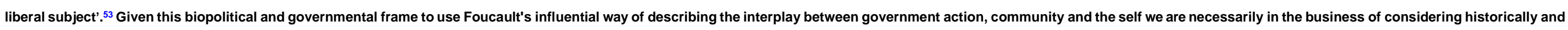
culturally inflected sanitary regimes. ${ }^{54}$ It is St. Petersburg's established urban culture of bathing and its marked resistance to attempts at municipal governmentalisation that deserves detailed emphasis.

\section{Bathhouse reform and regulation: communal bathing and disciplinarymodernity}

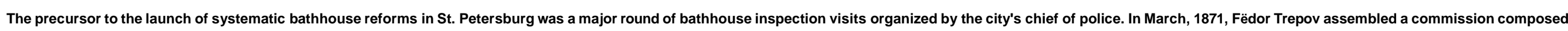

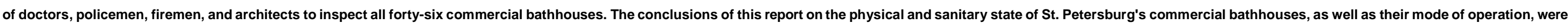

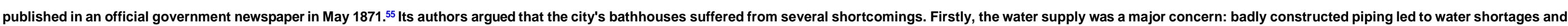

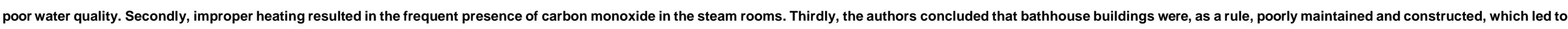
insanitary and potentially unsafe conditions across all sections. Draughts, poor ventilation, slippery or grimy floors, and the lack of evacuation routes were among the problems noted. ${ }^{56}$

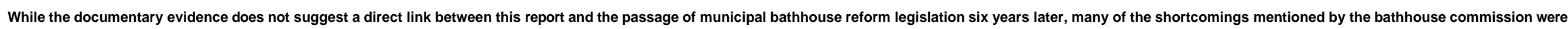

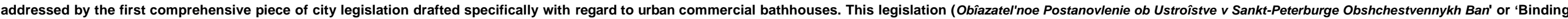

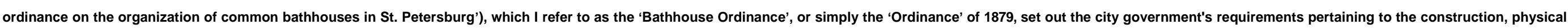

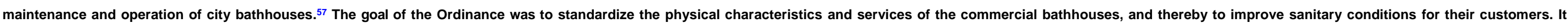

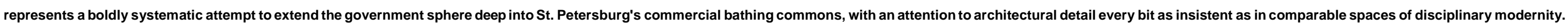

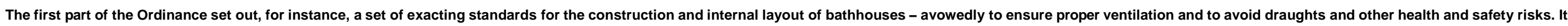

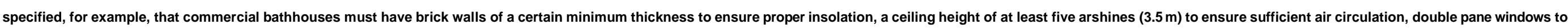

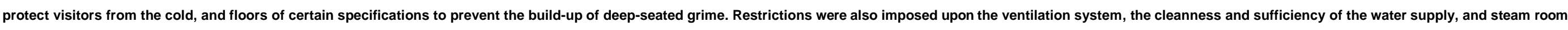

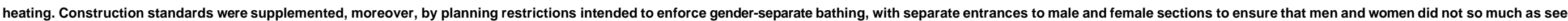
each other at the bathhouse, let alone bathe together. ${ }^{58}$

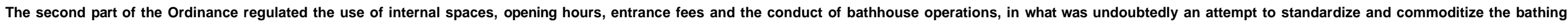

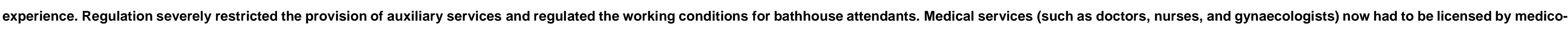

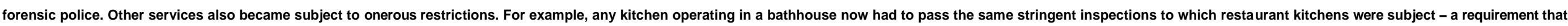

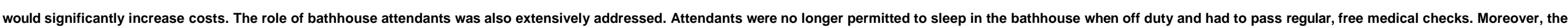

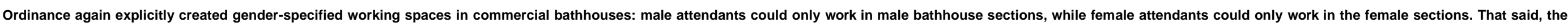

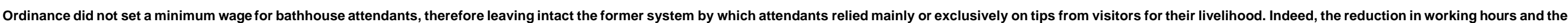

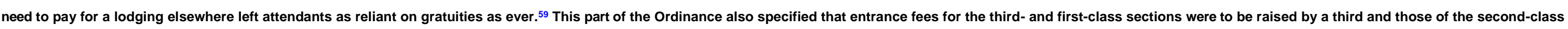
section by a quarter. 


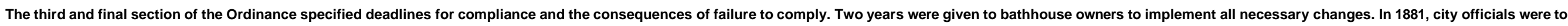
re-inspect all bathhouses, and those that did not comply would be temporarily or permanently closed and sealed. ${ }^{60}$

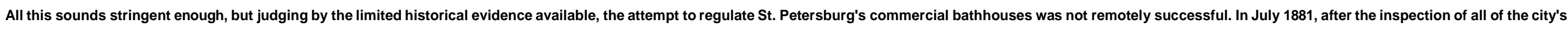

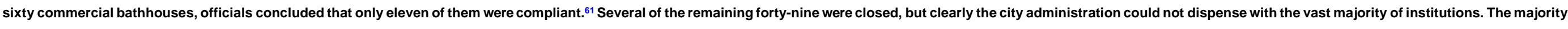

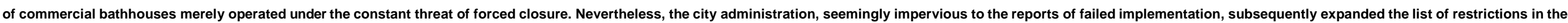

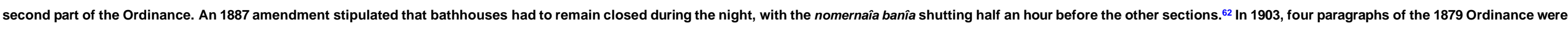

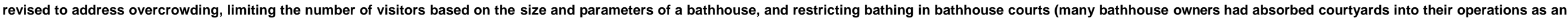
inexpensive measure to expand capacity). ${ }^{63}$

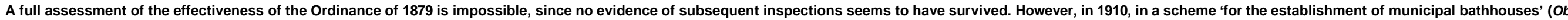

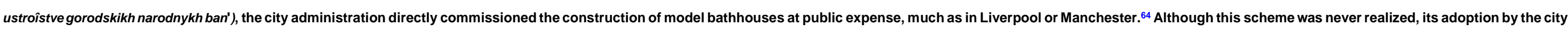

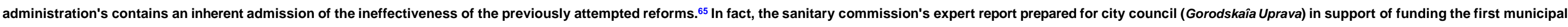

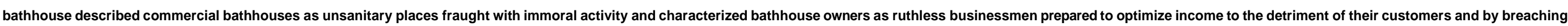

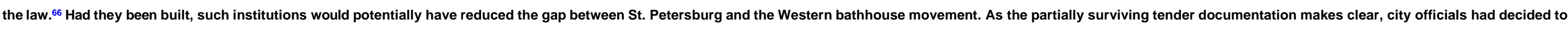
create sanitized and standardized 'factories for washing' combining the merits of recent innovations in construction technologies and hygiene. ${ }^{67}$

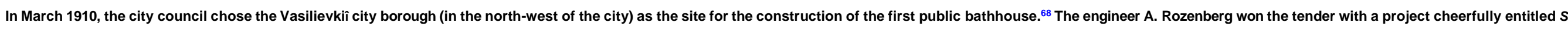

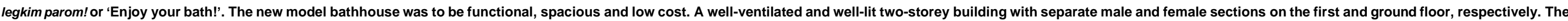

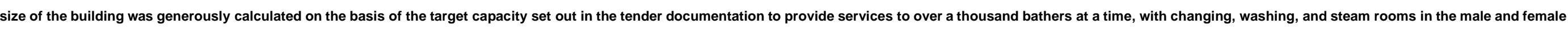

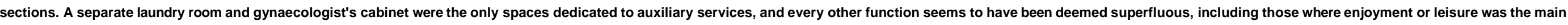

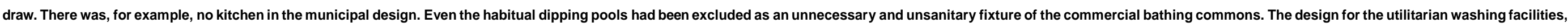

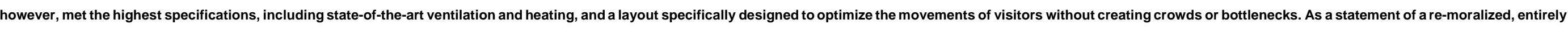
functional, bathing institution, the municipal bathhouse could hardly be bettered. ${ }^{69}$

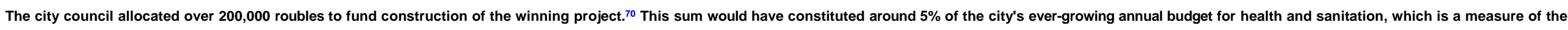

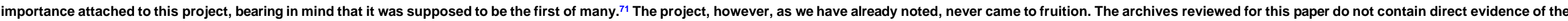

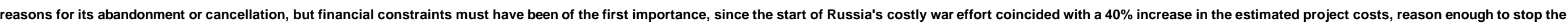
project. $^{72}$ That said, there were other, more structural and entrenched, problems that beset the attempt to bring communal bathing within the framework of municipal regulation.

\section{The bathing commons and the failure of municipal reform}

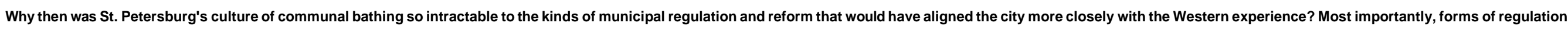

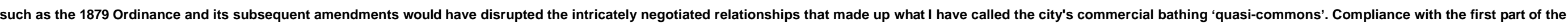

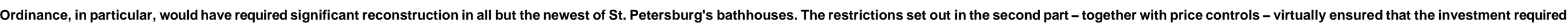

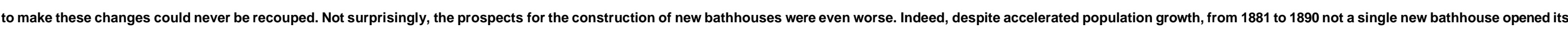

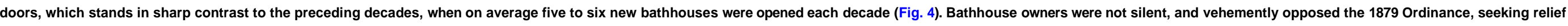

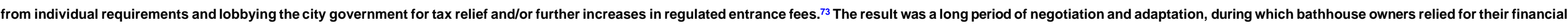

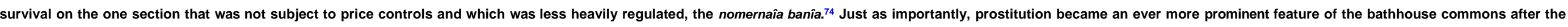

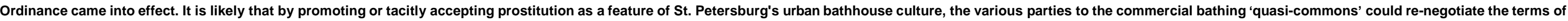
their cooperation and jointly re-established the sector's viability in the face of inept legislation. 


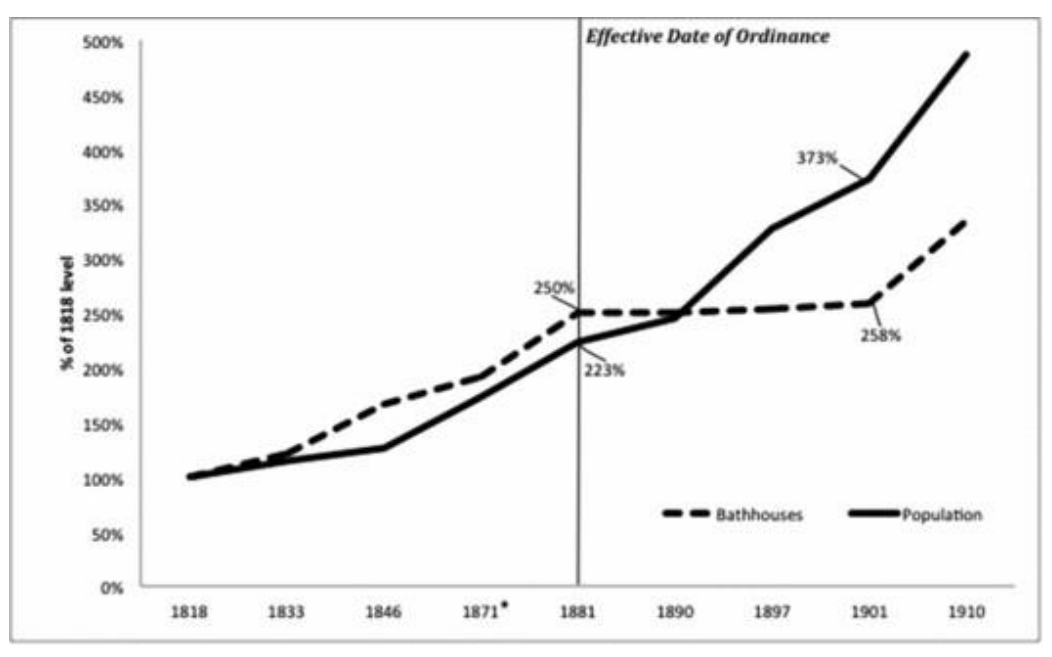

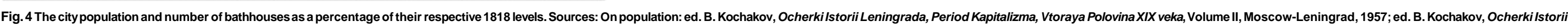

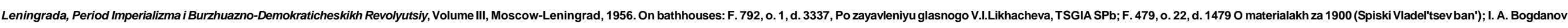
Tri Veka, $63 .{ }^{*} 1869$ for population.

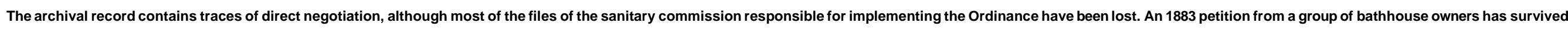

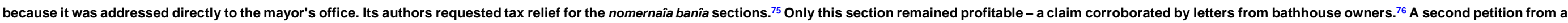

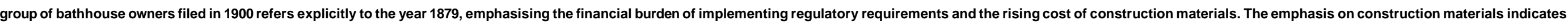

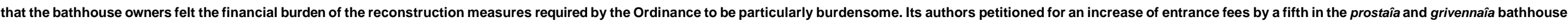

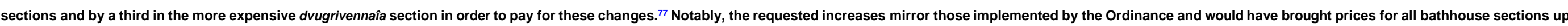

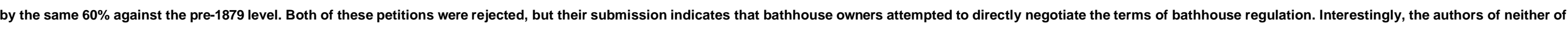

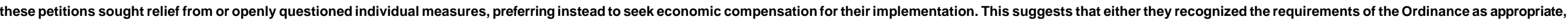
or wished to avoid questioning government authority even on matters intimately familiar to them.

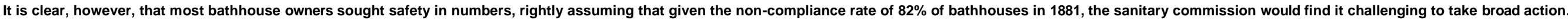

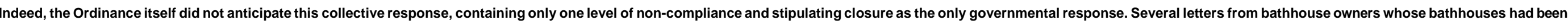

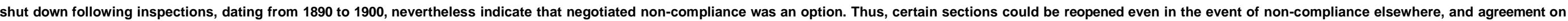
measures to address the most consequential breaches sufficed to warrant partial reopening.

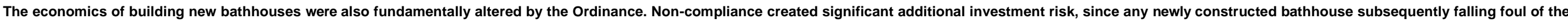

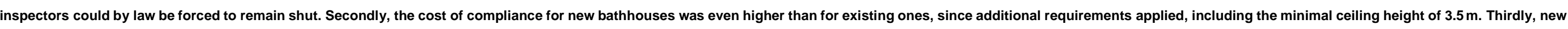

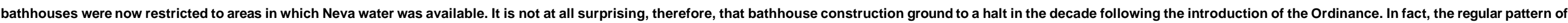

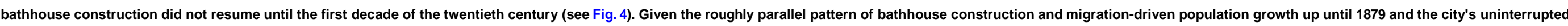

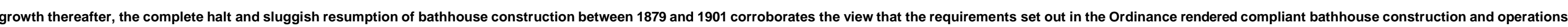

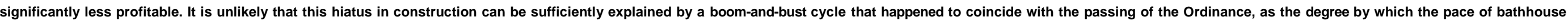

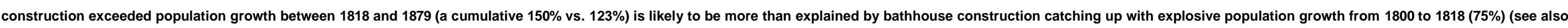
Fig. 4). This, however, cannot be definitively tested, since reliable data regarding bathhouse construction for the period preceding 1818 has not been found.

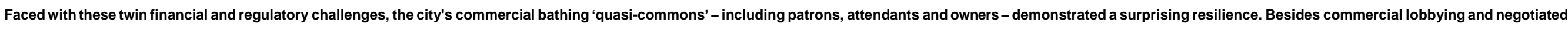




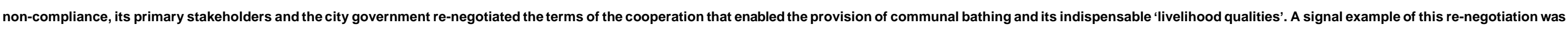

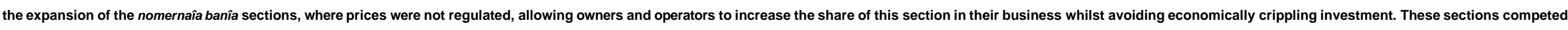

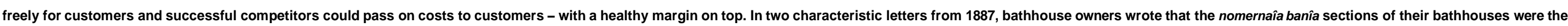

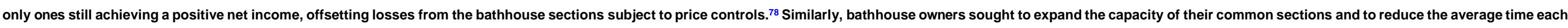

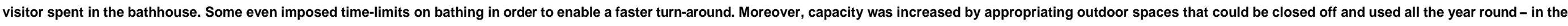

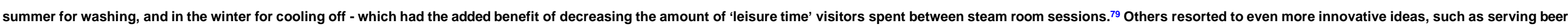
and a buffet in the entrance hall. ${ }^{80}$

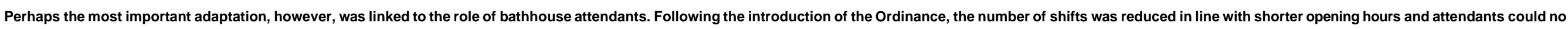

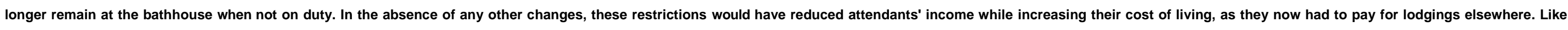

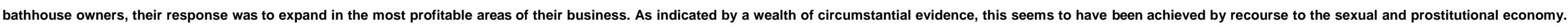

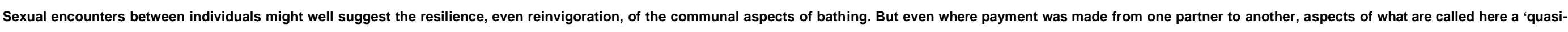

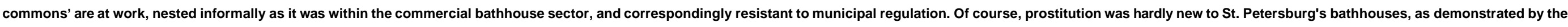

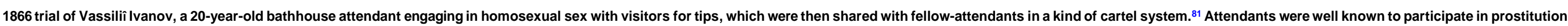

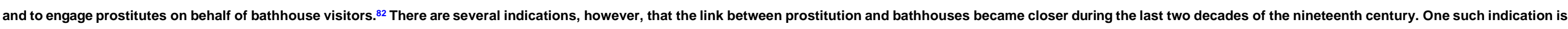

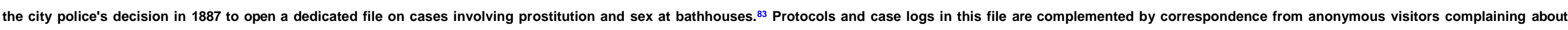

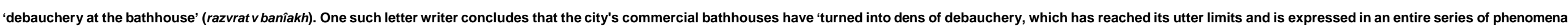

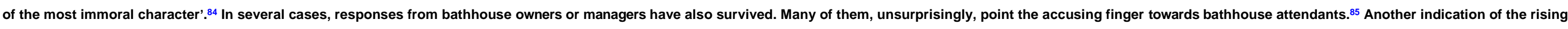

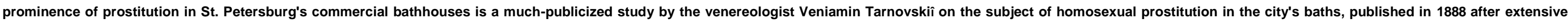

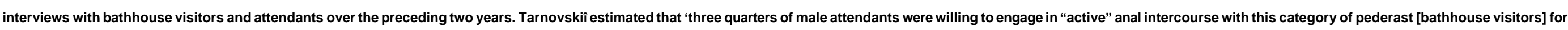

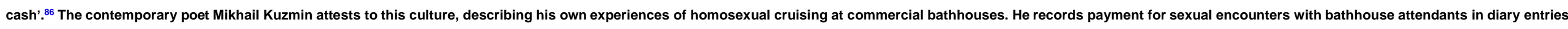
relating to the period from 1905 to 1907 . Two of Kuzmin's long-time lovers were bathhouse attendants, and he repeatedly expressed his fondness for the bania and the opportunity for sexual intimacy they provided. ${ }^{87}$

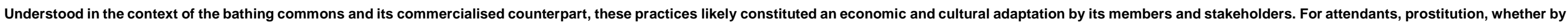

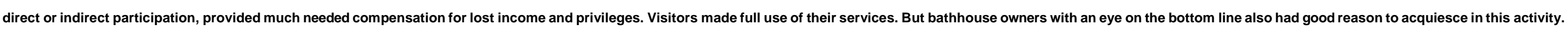
As the recipients of a higher income from the operations of their nomernaîa banîa, functioning as a 'hotel by the hour' for intimate encounters, they benefited from sex and sexual commerce at the bathhouse.

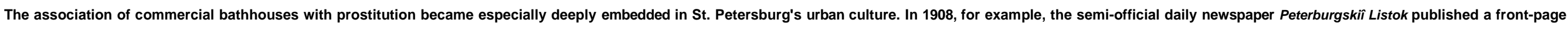

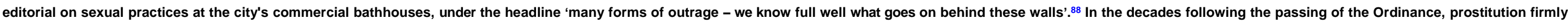

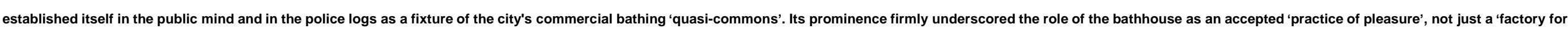

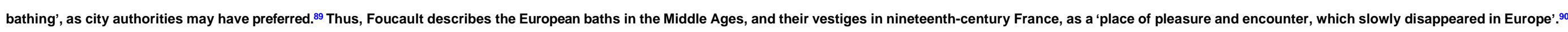

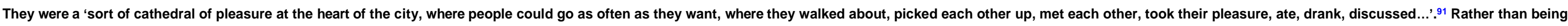

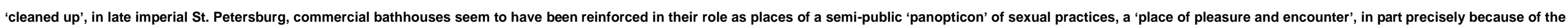
failure of regulation.

\section{Conclusion}

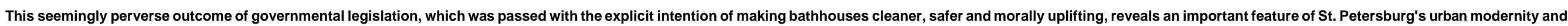

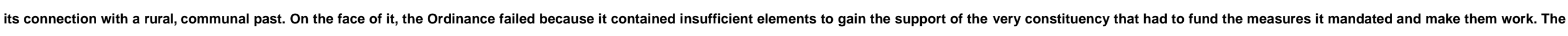

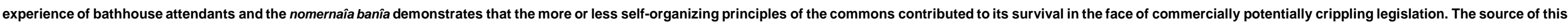

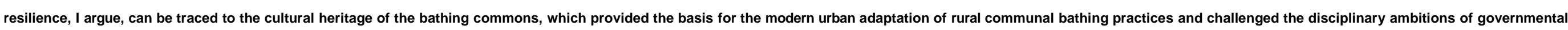




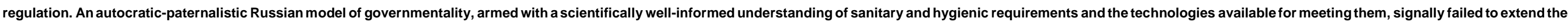

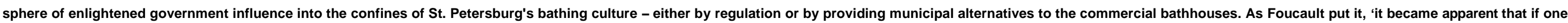

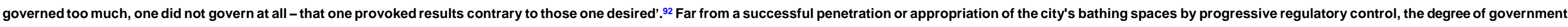

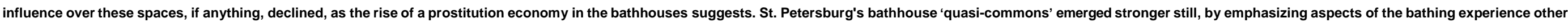

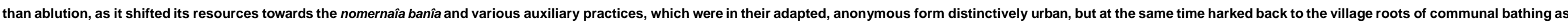

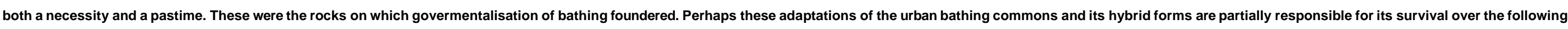

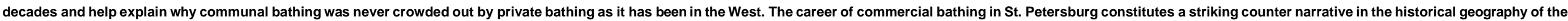
water revolution, hygienic modernity and liberal governmentality.

\section{Acknowledgements}

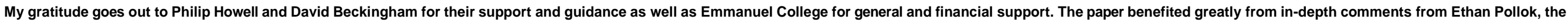

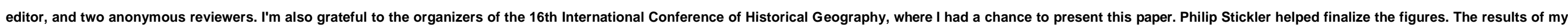
archival research owe much to the generous help of Mariîa Perikalina at the Russian State Historical Archive in St. Petersburg (TSGIA).

\section{Footnotes}

${ }^{1}$ D. Randall, Cracks in the granite: paternal care, the imperial façade, and the limits of authority in the 1824 St. Petersburg flood, Journal of Urban History 40 (2014) 480.

${ }^{2}$ With the exception of Ethan Pollock, see K. Kashin and E. Pollock, Public health and bathing in late imperial Russia: a statistical approach, The Russian Review 72 (2013) 66-93.

${ }^{3}$ A. Dubrovskîaa and V. Dubrovskiî, Russkaîa Banîa i Massazh, Moscow, 2008; N. Tolstoj, Slavîanskie Drevnosti: Ėtnolingvisticheskiî Slovar'v 5-ti Tomakh, Volume 1, Moscow, 1995.

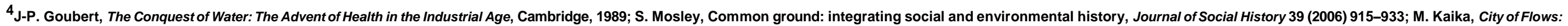

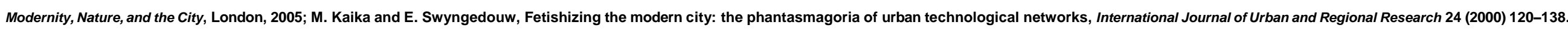

$5 \mathrm{M}$. Berman, All that is Solid Melts into Air: The Experience of Modernity, London, 1983, 173.

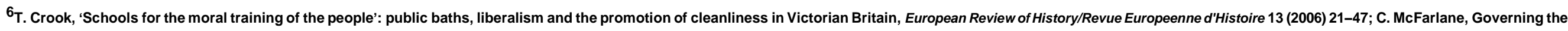
contaminated city: infrastructure and sanitation in colonial and post-colonial Bombay, International Journal of Urban and Regional Research 32 (2008) $415-435$.

${ }^{7}$ M. Gandy, The Fabric of Space: Water, Modernity, and the Urban Imagination, Cambridge MA, 2014, 13-14.

${ }^{8} \mathrm{~V}$. Taylor and F. Trentmann, Liquid politics: water and the politics of everyday life in the modern city, Past and Present 211 (2011) $199-241$.

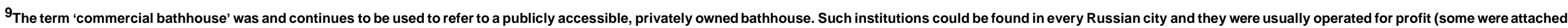
to factories and or other institutions). I use the definition proposed by Kashin and Pollock, Public health and bathing, 70.

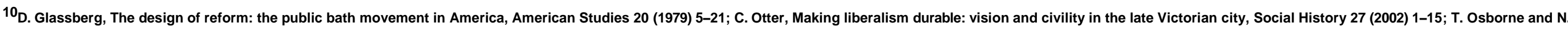

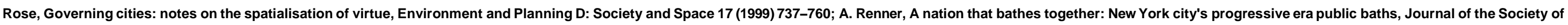
Architectural Historians 67 (2008) 504-531.

${ }^{11}$ Gandy, Fabric of Space, 13.

${ }^{12}$ A. Chekhov, V bane, in: A. Chekhov, Polnoe Sobranie Sochineniî i Pisem v Tridtsati Tomakh. Rasskazy. Îumoreski, 1884-1885, Volume 3, Moscow, 1975, 178-186. 
${ }^{13}$ S. Boym, Common Places: Mythologies of Everyday Life in Russia, Cambridge, MA, 2009.

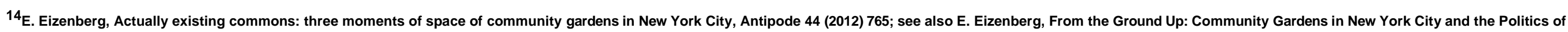
Spatial Transformation, Farnham, 2013.

${ }^{15}$ A.I. Bogdanov, Istoricheskoe, Geograficheskoe i Topograficheskoe Opisanie Sankt-Peterburga ot Nachala Zavedeniîa Ego, s 1703 po 1751 god, St. Petersburg, 1779.

16.A. Bogdanov, Tri Veka Peterburgskoî Bani, St. Petersburg, 2000.

${ }^{17}$ Bogdanov, Tri Veka, 27.

${ }^{18}$ Bogdanov, Istoricheskoe Opisanie Sankt-Peterburga.

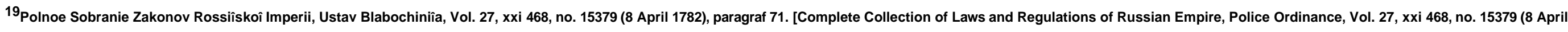
1782), article 71.

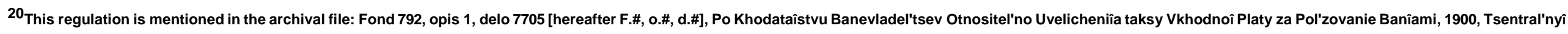
Gosudarstvennyî Istoricheskiî Arkhiv, Sankt-Peterburg, (Russian State Historical Archive in St. Petersburg) [hereafter TSGIA SPb].

${ }^{21}$ Crook, 'Schools for the moral training', 30, 32; M. Foucault, Discipline and Punish: The Birth of the Prison, translated by Alan Sheridan, London, 1991.

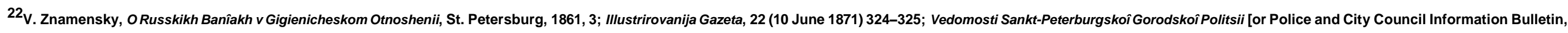
hereafter Vedomosti Polici], 119 (28 May 1871) 1-2.

${ }^{23}$ P. Bailey, Entertainmentality! Liberalizing modern pleasure in the Victorian leisure industry, in: S. Gunn and J. Vernon (Eds.), The Peculiarities of Liberal Modernity in Imperial Britain, Berkeley, $2011,126$.

${ }^{24}$ Znamensky, O Russkikh Baniakh, 34.

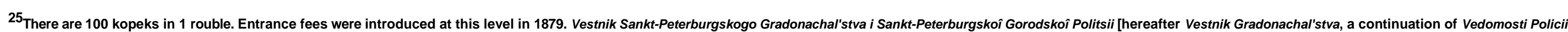
under a new name] 172 (29 July 1879) 1-2.

${ }^{26}$ Eizenberg, Actually existing commons, 766 .

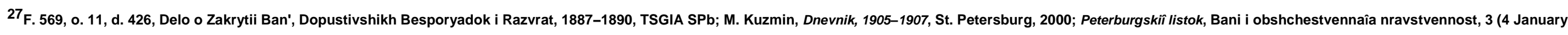
1908).

${ }^{28} \mathrm{~F} .479$, o. 22, d. 1479, O Materialakh za 1900, 1899-1900, TSGIA, SPb, where the number of buckets of water used per year is specified as basis for taxation.

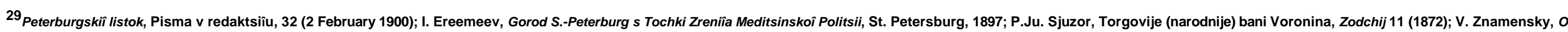
Russkikh Baniakh.

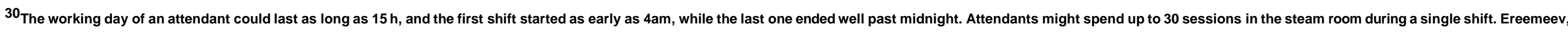
Gorod S.-Peterburg, 262-264, 515-516.

${ }^{31}$ Znamensky, O Russkikh Baniakh.

${ }^{32}$ N.A. Leykin, Stseny iz Kupecheskogo Byta, St. Peterburg, 1871, 113-115, 113.

${ }^{33}$ Znamensky, o Russkikh Baniakh, 39.

${ }^{34}$ Ereemeev, Gorod S.-Peterburg.

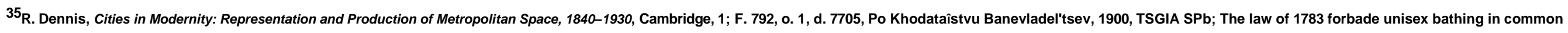

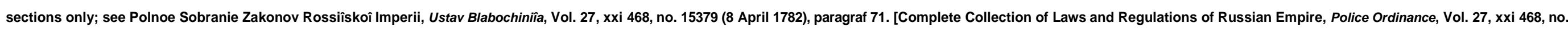
15379 (8 April 1782), article 71.]. 


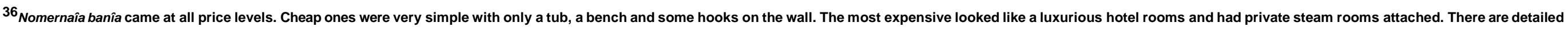
description of nomernia banîa in Ereemeev, Gorod S.-Peterburg; The Voronin bathhouse had a nomernaîa banîa with luxurious apartments consisting of several rooms, see Sjuzor, Torgovije (narodnije) bani.

${ }^{37}$ F. 569, o. 11, d. 426, Delo o Zakrytii Ban'.

${ }^{38}$ Eizenberg, Actually existing commons, 766.

${ }^{39}$ Znamensky, O Russkikh Baniakh.

${ }^{40} \mathrm{Here}$, and in the rest of this paragraph, I am following the spirit if not the letter of arguments in M. Hardt and A. Negri, Commonwealth, Cambridge MA, 2009.

${ }^{41}$ Sjuzor, Torgovije (narodnije) bani.

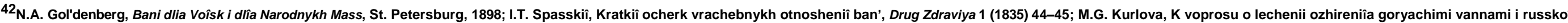

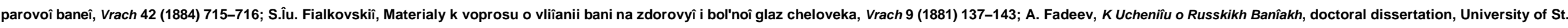

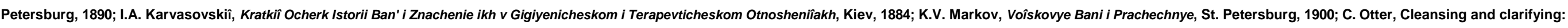
technology and perception in nineteenth-century London, Journal of British Studies 43 (2004) 40-64; Renner, A nation that bathes together; Crook, 'Schools for the moral training'.

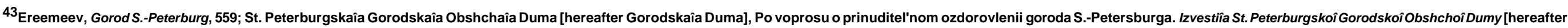

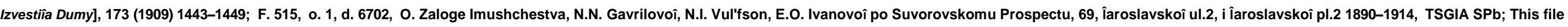

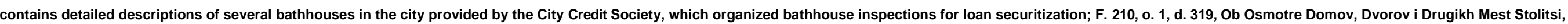
1908-1909, TSGIA SPb.

${ }^{44}$ Gorodskaîa Duma, Vodosnabzheniî v Peterburge, Izvestiîa Dumy 193 (1914) 2993-3000; Gorodskaîa Duma, O korennom uluchshenii vodosnabzheniîa S.-Peterburga, lzvestiîa Dumy 181 (1911) 577-587.

${ }^{45}$ F. 515, o. 1, d. 6702, O Zaloge Imushchestva, TSGIA SPb; F. 210, o. 1, d. 613, Ob Organizatsii i Deîatel'nosti Gorodskoî Sanitarnogo Nadzora, 1914, TSGIA SPb.

${ }^{46}$ Gorodskaîa Duma, Po voprosu o prinuditel'nom ozdorovlenii.

${ }^{47}$ Gorodskaîa Duma, Vodosnabzheniî v Peterburge.

${ }^{48}$ Renner, A nation that bathes together; Crook, 'Schools for the moral training'

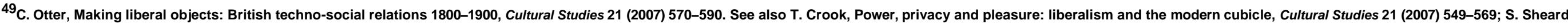
Profit is a dirty word: the development of public baths and wash-houses in Britain 1847-1915, Social History of Medicine 13 (2000) 63-86; P. Joyce, The Rule of Freedom: Liberalism and the Modern City, London, 2003.

${ }^{50}$ Crook, 'Schools for the moral training', 22.

51 McFarlane, Governing the contaminated city, 418.

${ }^{52}$ See the recently published monograph by Malcolm Shifrin, Victorian Turkish Baths, Historic England, 2015. Also available at http://www.victorianturkishbath.org/thebook.htm, last viewed on 4th November 2015.

${ }^{53}$ Otter, Making liberal objects, 580 .

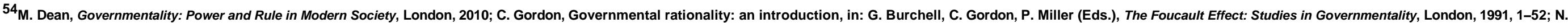

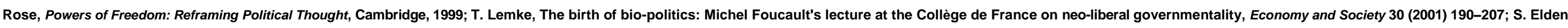

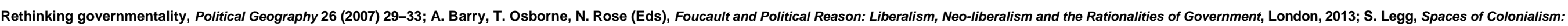
Delhi's Urban Governmentalities, Oxford, 2007; J.X. Inda, Anthropologies of Modernity: Foucault, Governmentality, and Life Politics, Oxford, 2008.

55 Vedomosti Politsii 118 (27 May 1871) 1-2; Vedomosti Politsii 119 (28 May 1871) 1-2.

${ }^{56}$ Vedomosti Politsii 118 (27 May 1871) 1-2; Vedomosti Politsii 119 (28 May 1871) 1-2.

57 Vestnik Gradonachar'stva 172 (29 July 1879) 1-2.

58 Vestnik Gradonachar' stva 172 (29 July 1879) 1 


\section{Vestnik Gradonachar'stva 172 (29 July 1879) 2.}

${ }^{60}$ F. 792, o.1, d. 3337, Po Zaîavlenîiui Glasnogo V.I.Likhacheva o Neispolnenii Upravoî Izdannogo v 1879 Obîazatel'nogo Postanovleniîa o Banîakh, 1882-1887, TSGIA SPb.

${ }^{61}$ F. 792, 0.1, d. 3337, Po Zaîavleniîu Glasnogo V.I.Likhacheva, TSGIA SPb.

${ }^{62}$ F. 792, 0.1, d. 3337, Po Zaîavleniîu Glasnogo V.I.Likhacheva, TSGIA, SPb, 10.

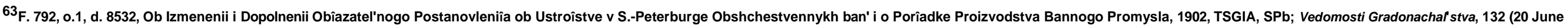
1903) 1.

64F. 210, o. 1, d. 484, Ob Ustroystve Gorodskikh Narodnykh ban', 1910-1916, TSGIA SPb.

${ }^{65}$ F. 210, o. 1, d. 484, Ob Ustroîstve, TSGIA SPb; see also F. 569, o. 11, d. 426 Delo o Zakrytii ban', TSGIA SPb.

${ }^{66}$ F. 210, o. 1, d. 484, Ob Ustroîstve, TSGIA SPb.

${ }^{67}$ Gol'denberg, Bani dlia Voîsk.

${ }^{68}$ F. 210, o. 1, d. 484, Ob Ustroîstve, TSGIA SPb.

${ }^{69}$ F. 210, o. 1, d. 484, Ob Ustroîstve, TSGIA SPb.

${ }^{70}$ M. Fedorov, Finansovoje polozenije Peterburga, Gorodskoje Delo 1 (1909) 13.

71 F. 210, o. 1, d. 484, Ob Ustroîstve, TSGIA SPb.

${ }^{72}$ F. 210, o. 1, d. 484, Ob Ustroîstve, TSGIA SPb.

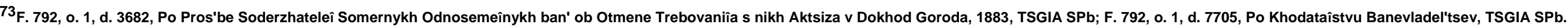

${ }^{74}$ Vestnik Gradonachal'stva 172 (29 July 1879) 2.

${ }^{75}$ F. 792, o. 1, d. 3682, Po Pros'be Soderzhateleî, TSGIA SPb.

${ }^{76}$ F. 569, o. 11, d. 426, Delo o Zakrytii ban', TSGIA SPb.

77F. 792, o. 1, d. 7705, Po Khodataîstvu Banevladel'tsev, TSGIA SPb.

${ }^{78}$ F. 569, o. 11, d. 426, Delo o Zakrytii ban', TSGIA SPb, letter from Timofeî Krîukov, 28--28v or from Ivan Petrov, 35v.

${ }^{79}$ Sjuzor, Torgovije (narodnie) bani.

${ }^{80}$ Peterburgskii Listok, Pis'ma v redaktsiîu, 32 (2 February 1900).

${ }^{81}$ V.M. Tarnovskiî, Izvrashchenie Polovogo Chuvstva, Sudebno-Psikhiatricheskiî Ocherk, St. Petersburg, 1885, 69.

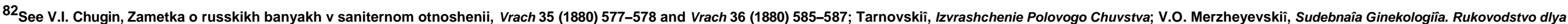

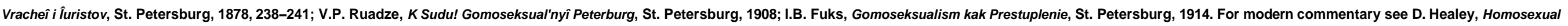

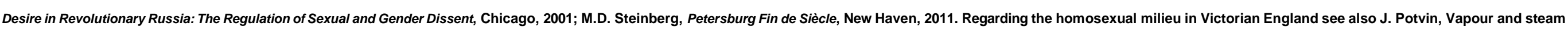
the Victorian Turkish bath, homosocial health, and male bodies on display, Journal of Design History 18 (2005) 319-333.

${ }^{83}$ F. 569, o. 11, d. 426, Delo o Zakrytii ban', TSGIA SPb.

${ }^{84}$ F. 569, o. 11, d. 426, Delo o Zakrytii ban', TSGIA SPb, 5 r.

${ }^{85}$ F. 569, o. 11, d. 426, Delo o Zakrytii ban', TSGIA SPb, for example, letter from Ivan Gustov, 22r-22v.

${ }^{86}$ Healey, Homosexual Desire, 28. 


\section{${ }^{87}$ Kuzmin, Dnevnik.}

${ }^{88}$ Peterburgskii listok, Bani i obshchestvenaîa nravstvennost, 3 (4 January 1908).

89 Vedomosti Policii, 119 (28 May 1871).

${ }^{90}$ P. Rabinow, The Foucault Reader, London, 1991, 251.

${ }^{91}$ Rabinow, The Foucault Reader, 251.

${ }^{92}$ Rabinow, The Foucault Reader, 242.

Highlights

- Analyses commercial bathhouses and bathing culture in imperial St. Petersburg

- Adds to the literature on hygienic modernity and its water revolution.

- Describes communal bathing and the development of a hybrid form, a 'quasi-commons'.

- Contributes to the historical geography of govermentality and social regulation.

- Challenges the centrality of Western experience in the discussion of urban modernity. 